\title{
Elan's transgenic mouse back in the running
}

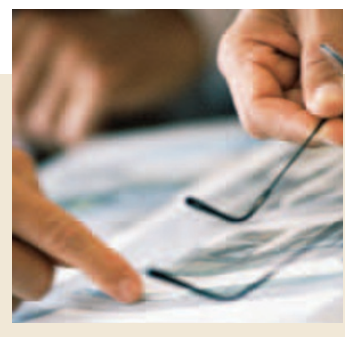

The US Court of Appeals for the Federal Circuit has revived an Elan lawsuit that the company filed against the Mayo Foundation for Medical Education and Research over Elan's genetically engineered mouse model for Alzheimer's disease research. In the third chapter of this ongoing saga, the case returned to a Federal Circuit three-person panel after the original decision was vacated by the en banc court - that is, the matter was referred to all the circuit judges in regular active service.

The crux of this case had centred around the doctrine of inherency, the understanding that information inherent in a patent belongs in the public domain, even if it was not known directly at the time of filing. Elan argued that their transgenic mice were not inherent in an earlier-filed patent by the inventor Mullan and the Mayo Foundation. Elan's US patent 5,455,169 concerns rodents transgenic for the 'Swedish mutation', a mutation found in humans that has been associated with Alzheimer's disease. Elan's claims further require that the transgenic rodent could produce sufficient levels of activating transcription factor-amyloid precursor protein (ATF-APP) to be detectable in a brain homogenate.

Previously, the District Court had decided that the patent by Mullan had discussed the possibility of creating transgenic animals based on the Swedish mutation of APP, and therefore reasoned that the remaining characteristics of Elan's claimed transgenic mouse would have been inherently recognized in the Mullan disclosure patent by those skilled in the art at the time that the Mullan patent was filed. In its appeal, Elan argued that Mullan's disclosure was not sufficient to anticipate Elan's invention either explicitly or inherently, because ATF-APP had not been disclosed in humans until after the Mullan patent was filed, and so would not have been recognized as inherent within Mullan's disclosure at that time.

However, the Federal Circuit concluded that the language and factual basis of Elan's argument encompassed the question of enablement, rather than inherency arguments — that is, there was enough knowledge in the public domain for enablement of Elan's transgenic mice by the filing date of the Elan patent. The District Court had not directly addressed the question of enablement, therefore, the Federal Circuit remanded the case back to the lower court for determination of whether the Mullan patent enabled persons of ordinary skill in the field of the invention to make the desired mutated mouse without undue experimentation.

Elan Pharmaceuticals, Inc. v. Mayo Foundation for Medical Education and Research No. 00-1467 (October 2, 2003). Opinion by Newman, joined by Gajarsa and Dyk: http://fedcir.gov/opinions/00-1467a.doc

\section{Merck's acid dissolves Teva's salt}

When Teva filed an Abbreviated New Drug Application (ANDA) for a proposed generic version of Merck's drug Fosamax, Merck filed a patent infringement action. In a twoto-one decision, the Court of Appeals for the Federal Circuit confirmed that Merck's US patent 4,621,077 is valid and would be infringed by the generics manufacturer. The ' 077 patent claims a method of treatment using a particular acid; Merck markets Fosamax, the monosodium salt trihydrate of the acid (alendronate sodium), for the treatment of osteoporosis, for both daily and weekly administration. Teva's defence was that the patent is invalid because the approved product is not the acid, but the monosodium salt, and that Merck's claim requires the acid, whereas Teva's ANDA is for the salt. The court noted that throughout the patent specification the inventors described the acid active agent as encompassing the acid and its salt forms. As a result of the court's decision, Merck's patent is set to expire in August 2007. Because Merck is entitled to an additional six months of marketing exclusivity following patent expiration, the earliest date for marketing of generic alendronate for daily administration is February 2008.

Merck and Co., Inc., versus Teva Pharms, Inc., No. 03-1168 (October 30, 2003). Opinion by Newman; Dissent by Mayer: http://fedcir.gov/opinions/03-1168.doc

\section{Interference decision upheld}

In an interference action covering fluorotaxol (a compound related to taxol that is used to treat cancer), the US Court of Appeals for the Federal Circuit has affirmed a US Patent and Trademark Office (USPTO) Board of Appeals decision. The USPTO declared interference between Shu-Hui Chen's patent $(5,254,580$, assigned to Bristol-Myers Squibb) and Herve Bouchard's application (assigned to RhonePoulenc), finding priority for Bouchard. An interference is a proceeding declared by the USPTO when two or more parties claim the same invention. Evidence of conception that is, the creation of the mental concept of the invention - is presented, as well as of reduction to practice (that is, the physical part of the inventive process that completes the process of invention). Until there is a reduction to practice, there is no invention.
On 1 July 1992, Chen filed a series of patent claims directed towards fluorotaxols. Chen later discovered that the method he had previously disclosed produced cyclopropataxol derivatives. So, on 19 January 1993 Chen withdrew the original application and filed new claims directed towards cyclopropataxols. The Bouchard application directed towards cyclopropataxols was filed on 8 December 1993, but was given the earlier filing date of Bouchard's French application, 9 December 1992.

The court affirmed the USPTO's determination that Chen's prior application did not disclose, either expressly or inherently, the cyclopropataxols. The court found that the claims and information directed towards cyclopropataxols added new matter, rather than merely correcting a mistaken description of the earlier method, and noted that the inventors described the formation of cyclopropataxols as a surprising result. The court also concluded that Chen failed to demonstrate that he had conceived and reduced to practice the formation of the cyclopropataxols prior to Bouchard.

Chen versus Bouchard, No. 03-1037 (October 22, 2003). Opinion by Lourie joined by Schall; Dissent in part by Newman: http://fedcir.gov/opinions/03-1037.doc 